\title{
Neuroendocrine factors: The missing link in non-melanoma skin cancer (Review)
}

\author{
MIHAI LUPU $^{1 *}$, ANA CARUNTU ${ }^{2,3^{*}}$, CONSTANTIN CARUNTU $^{4,5}$, LAURA MARIA LUCIA PAPAGHEORGHE ${ }^{6}$, \\ MIHAELA ADRIANA ILIE ${ }^{7}$, VLAD VOICULESCU ${ }^{8}$, DANIEL BODA ${ }^{7}$, CAROLINA CONSTANTIN $^{9,10}$, \\ CRISTIANA TANASE ${ }^{3,9}$, MARIA SIFAKI ${ }^{11}$, NIKOLAOS DRAKOULIS ${ }^{12}$, CHARALAMPOS MAMOULAKIS $^{13}$, \\ GEORGE TZANAKAKIS ${ }^{14}$, MONICA NEAGU ${ }^{9,10}$, DEMETRIOS A. SPANDIDOS ${ }^{15}$, \\ BORIS N. IZOTOV ${ }^{16}$ and ARISTIDES M. TSATSAKIS ${ }^{11}$
}

${ }^{1}$ Department of Dermatology, MEDAS Medical Center, 030442 Bucharest; ${ }^{2}$ Department of Oral and Maxillofacial Surgery, 'Carol Davila' Central Military Emergency Hospital, 010825 Bucharest; ${ }^{3}$ 'Titu Maiorescu' University, Faculty of Medicine, 031593 Bucharest; ${ }^{4}$ Department of Physiology, 'Carol Davila' University of Medicine and Pharmacy, 050474 Bucharest;

${ }^{5}$ Department of Dermatology, 'Prof. N. Paulescu' National Institute of Diabetes, Nutrition and Metabolic Diseases, 011233 Bucharest;

${ }^{6}$ Dermatology Ambulatory Center, 'Colțea' Clinical Hospital, 030171 Bucharest; ${ }^{7}$ Dermatology Research Laboratory,

'Carol Davila' University of Medicine and Pharmacy, 050474 Bucharest; ${ }^{8}$ Department of Dermatology and Allergology, Elias Emergency University Hospital, 011461 Bucharest; ${ }^{9}$ 'Victor Babes' National Institute of Pathology, 050096 Bucharest; ${ }^{10}$ Colentina University Hospital, 020125 Bucharest, Romania; ${ }^{11}$ Laboratory of Toxicology, Faculty of Medicine, University of Crete, 71003 Heraklion; ${ }^{12}$ Research Group of Clinical Pharmacology and Pharmacogenomics, Faculty of Pharmacy, School of Health Sciences, National and Kapodistrian University of Athens, 15771 Athens; ${ }^{13}$ Department of Urology, University General Hospital of Heraklion, University of Crete Medical School; ${ }^{14}$ Laboratory of Anatomy-Histology-Embryology, School of Medicine; ${ }^{15}$ Laboratory of Clinical Virology, Medical School, University of Crete, 71003 Heraklion, Greece; ${ }^{16}$ Department of Analytical Toxicology, Pharmaceutical Chemistry and Pharmacognosy, Sechenov University, 119991 Moscow, Russia

Received February 23, 2017; Accepted June 29, 2017

DOI: 10.3892/or.2017.5817

\begin{abstract}
Non-melanoma skin cancer (NMSC) is the most common form of cancer worldwide, comprising $95 \%$ of all cutaneous malignancies and approximately $40 \%$ of all cancers. In spite of intensive efforts aimed towards awareness campaigns and sun-protective measures, epidemiological data indicate an increase in the incidence of NMSC. This category of skin cancers has many common environmental triggers. Arising primarily on sun-exposed skin, it has been shown that ultraviolet radiation is, in the majority of cases, the main trigger involved in the pathogenesis of NMSC. Aside from the well-known etiopathogenic factors, studies have indicated that several neuroactive factors are involved in the carcinogenesis of two of the most common types of NMSC, namely basal cell carcinoma (BCC) and squamous cell carcinoma (SCC), with the exception of penile SCC, for which a paucity of specific data on their pathogenic role
\end{abstract}

Correspondence to: Dr Constantin Caruntu, Department of Physiology, 'Carol Davila' University of Medicine and Pharmacy, 8 Eroii Sanitari Avenue, 050474 Bucharest, Romania

E-mail: costin.caruntu@gmail.com

${ }^{*}$ Contributed equally

Key words: basal cell carcinoma, inflammation, neurohormones, neuromediators, neuropeptides, photo-carcinogenesis, squamous cell carcinoma, penile neoplasms exists. The complex interaction between the peripheral nervous system and target cells in the skin appears to be mediated by locally released neuroendocrine factors, such as catecholamines, substance $\mathrm{P}$, calcitonin gene-related peptide and somatostatin, as well as neurohormones, such as proopiomelanocortin and its derived peptides, $\alpha$-melanocyte-stimulating hormone and adrenocorticotropin. All these factors have been, at least at some point, a subject of debate regarding their precise role in the pathogenesis of NMSC. There is also a significant body of evidence indicating that psychological stress is a crucial impact factor influencing the course of skin cancers, including SCC and BCC. Numerous studies have suggested that neuroendocrine factor dysregulation, as observed in stress reactions, may be involved in tumorigenesis, accelerating the development and progression, and suppressing the regression of NMSC. Further studies are required in order to elucidate the exact mechanisms through which neuroactive molecules promote or inhibit cutaneous carcinogenesis, as this could lead to the development of more sophisticated and tailored treatment protocols, as well as open new perspectives in skin cancer research.

\section{Contents}

1. Introduction

2. Stress

3. Neuroactive mediators

4. Cellular neuro-immune interactions

5. Conclusion and perspectives 


\section{Introduction}

The skin is both a physical barrier between the host and the environment, as well as an immunological gatekeeper destined to optimally fulfill the needs of the host. Thus, the interactions between the external factors and the internal environment of the skin significantly affect both skin homeostasis, as well as the incidence of skin pathologies (1).

Comprising basal cell carcinoma (BCC) and squamous cell carcinoma (SCC), together with a large number of rare tumors, non-melanoma skin cancer (NMSC) is the most common form of cancer worldwide, encompassing $95 \%$ of all cutaneous neoplasms and approximately $40 \%$ of all malignancies $(2,3)$. Despite growing awareness and sun-protective measures, the incidence of NMSC has markedly increased over the past decades (4). Due to the current age shift in the population, mainly in developed countries, the incidence of NMSC may increase by an estimated $50 \%$ by the year $2030(4,5)$.

$\mathrm{BCC}$ is the most frequently occurring form of skin cancer ( $80 \%$ of all skin cancers), accounting for one third of all cancers per year $(6,7)$. While BCCs rarely exhibit an unrestrained behavior, SCCs are more aggressive and metastasize more frequently. SCCs represent over $20 \%$ of all cutaneous malignancies, and $14 \%$ of these tumors metastasize and are responsible for the majority of deaths due to NMSC (8-13). Furthermore, SCC is the most frequently reported pathology of penile cancer $(>95 \%)$; this is a rare malignancy accounting for $0.24 \%$ of all neoplasms among males in the United States with a significantly higher incidence (up to 20-30-fold greater) in areas of Africa and South America, that usually arises from the epithelium of the inner prepuce or the glans, and it exists in several histological subtypes and shares a similar pathology with SCC of other origins (14-16). As a direct consequence, NMSCs add a considerable financial burden to healthcare systems, significantly reducing the quality of life of patients and having a marked socio-economic impact. Thus, continuous efforts are being made towards the identification of novel etiopathogenic mechanisms.

NMSCs have many common environmental triggers, some stimulating tumor development more than others. The major risk factors for NMSCs are chronic exposure to ultraviolet radiation (UVR), the thinning of the ozone layer due to pollution, non-specific immune suppression, the increased lifespan, protein patched homolog $1(\mathrm{PTCH})$ gene mutations and fair skin (17). Human papilloma virus (HPV) infection is an important risk factor for penile SCC; viral DNA has been detected in $70-100 \%$ of penile intraepithelial neoplasia and in $30-40 \%$ of invasive cancer tissue samples (15). HPV infection (particularly by high risk HPV types $16,18,31,33,35,56$ and 64 ) is nowadays recognized as a major co-factor in penile SCC through oncogenes and tumor suppressor genes (p53, pRb, p16) $(16,18)$. Nevertheless, it is now clear that apart from the HPV-induced pathway (through which up to $50-80 \%$ of penile SCC cases arise), a non-HPV-induced pathway represents a divergent molecular pathway accounting for penile carcinogenesis related to several risk factors, such as chronic inflamation and specific mediators $(16,19)$.

The fact that NMSC arises mostly on sun-exposed areas (with the exception of penile SCC) has highlighted the crucial role of UVR in the pathogenesis of NMSC. The effects of UVR exposure include DNA alteration, epidermal inflammation and hyperplasia, creating favorable conditions for the development of cutaneous malignancies (20-22). UVR is the principal cause of the occurrence of NMSC. Due to the interaction of the external environment with the internal mechanisms of the human organism, factors that influence the functions of the human body also affect the appearance and/or progression of precancerous lesions $(23,24)$. Thus, an underactive and poor performing immune system causes these lesions to rapidly appear and develop, while a strong immune system may prevent the appearance and development of NMSC $(23,24)$. The immunosuppressive-inducing effects of UVR are primarily cited as conditioning a permissive tumor microenvironment for BCC and SCC. Several studies have confirmed that the immune system has a significant influence on the development of skin tumors, by creating a microenvironment favorable for carcinogenesis. However, these effects may be insufficient to induce carcinogenesis (25-29). Moreover, various neuroendocrine stimuli may potentiate and maintain a chronic state of inflammation, promoting tumorigenesis (Fig. 1) (30-33). Importantly, the function of the skin as a peripheral neuroendocrine organ has been well established. Thus, signals of cutaneous origin but related to the neuroendocrine system may trigger cascades of responses addressed at maintaining local and global homeostasis. The neuroendocrine function of the skin is performed by cells of mesenchymal, neural crest, bone marrow and epithelial origin that are compartmentally arranged into endocrine units localized at the epidermis, dermis and adnexal structures. These cells produce the respective hormones and express the corresponding receptors, suggesting that the main interactive mechanisms within the distinct cutaneous domains are of both autocrine and paracrine capacity (34). Moreover, cutaneous nerve fibers provide additional levels of communication with the release of neuropeptides at dermal or epidermal levels. The true endocrine component of the cutaneous neuroendocrine system is thus represented by those humoral signals that can directly enter the circulation (35). Therefore, the skin can generate signals to produce rapid or slow responses at local or systemic level. These signals counteract the environmental insults and/or internal functions. Thus, the skin can be characterized as a sensor for external or internal factors, which are subsequently translated by the cutaneous neuroendocrine system into humoral or neural signals and dispatched to local or distant coordinating centers (35).

Various studies have suggested a link between neuroendocrine factors and skin carcinogenesis in the two most common types of NMSC, BCC and SCC, with the exception of penile SCC, for which a paucity of specific data on their pathogenic role exists. A complex interaction between nervous system and target cells, such as keratinocytes, melanocytes, Langerhans cells (LCs), mast cells, endothelial cells and inflammatory infiltrate cells has been previously described in skin. This interaction appears to be mediated by locally released neuroendocrine factors encompassing classic neurotransmitters, neuropeptides and neurohormones (36-39). The mechanisms through which neuroendocrine factors influence mucocutaneous physiopathological processes are extremely complex, involving the dysregulation of the dynamic balance between the nervous, endocrine and immune systems (40). While NMSCs are highly immunogenic, the 


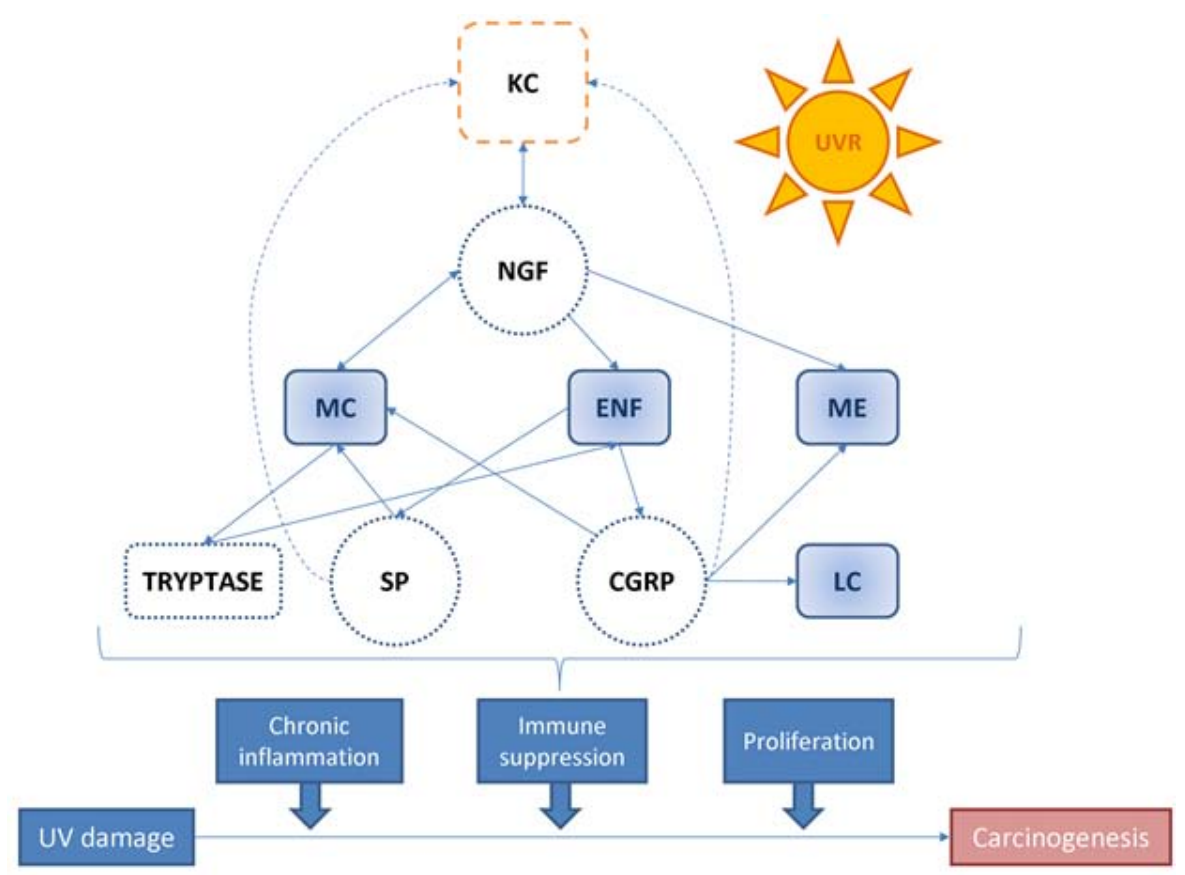

Figure 1. The cutaneous neuroendocrine system in photo-carcinogenesis. The image depicts the potential role of neuropeptides substance $\mathrm{P}$ (SP), calcitonin gene-related peptide (CGRP) and nerve growth factor (NGF) as modulating agents of keratinocytes (KCs), mast cells (MCs), epidermal nerve fibers (ENFs), melanocytes (MEs) and Langerhans cells (LCs). Damage induced by the exposure to ultraviolet radiation (UVR) leads to chronic inflammation, immunosuppression and cell proliferation, thus promoting carcinogenesis.

action of neuroendocrine factors, when combined with other appropriate factors, such as UVRs, may result in either the development of SCC or BCC $(30,31)$.

The aim of this review was to provide an overview of the neuroendocrine factors role in the initiation and/or promotion of NMSC (with a focus on SCC and BCC) in relation to environmental factor exposure.

\section{Stress}

Psychological stress is involved in the onset or aggravation of numerous skin pathophysiological processes $(37-39,41,42)$. In addition, a significant body of evidence suggests that stress is a crucial impact factor influencing the course of skin cancers $(38,43-45)$. Neuroendocrine factor dysregulation, as observed in stress reactions, may be involved in the modulation of tumorigenesis, accelerating the development and progression, and suppressing the regression of cancer.

Chronic stress. Alterations in the functionality of the immune system and promotion of tumor development (46) have been proven to represent the long-term effects of chronic stress exposure. Even without any obvious impact on the general health status, a moderate but chronic stress factor seems to lead to a substantial increase in skin cancer susceptibility in affected individuals. Moreover, the negative impact of stress factors on clinical, cellular and molecular parameters adding up to immunosuppression can be observed for months, even after the stressors have ceased their activity (31).

Studying skin tumor development in rat models, Saul et al (31) demonstrated that stressed mice exposed to UVB radiation developed skin malignancies in a shorter timeframe and that the stressed study group reached $50 \%$ tumoral incidence earlier than the non-stressed control group. Another study by Parker et al (47) demonstrated accelerated tumor development in an extended chronic stress model, in which stress factor administration began 2 weeks prior to UVR exposure. Furthermore, as previously demonstrated, stressed mice exhibit reduced values of interferon (IFN)- $\gamma$, CCL27/CTACK (expressed predominantly in the skin and responsible for $\mathrm{T}$ cell recruitment) (48), CD3 $\varepsilon$ (considered an important indicator of $\mathrm{T}$ cell infiltration) and interleukin (IL)-12p40 gene expression, as well as a reduced $\mathrm{CD} 4^{+}$cell count and an increased number of $\mathrm{CD}^{2} 5^{+}$suppressor cells in peritumoral infiltrates. IFN- $\gamma$, which promotes tumor recognition and destruction (49), is an essential mediator of IL-12-related antitumoral effects (50), and promotes tumor suppression (51). The authors hence concluded that chronic stress increases UVB-induced cutaneous SCC in their rat model, primarily by suppressing type 1 cytokine production and increasing $\mathrm{T}$ suppressor cell count (51). Furthermore, it has been shown that basal corticosterone levels in stressed mice remain higher than those in the control group for almost 7 months following the cessation of stress factors (51). Importantly, higher morning corticosterone levels indicate a circadian rhythm disturbance, leading to immune function impairment (52), accelerated tumor progression (53-55) and increased mortality (56).

Due to its immunosuppressive effect, chronic stress also creates a permissive environment for BCC tumorigenesis $(30,31)$. Transplant patients, as well as patients receiving moderate doses of immunosuppressive therapies are more susceptible to developing BCC than the general population (57), since the immune system is central to BCC appearance and progression. Fagundes et al showed that patients with BCC who experienced a stressful event in the past year or who had been maltreated in childhood had a poorer antitumor immune 
response (30). Of note, messenger RNA encoding for proteins expressed on immune cells, such as CD3e, CD68, CD25 and ICAM-1 are indicators of a targeted anti-BCC immune response. Patients who reported early childhood abuse had lower mRNA levels of CD3e, CD68, CD25 and ICAM-1, illustrating a tolerant microenvironment for tumor development (30). The results from the study by Saul et al concerning SCC in mouse models could also be applicable to BCC, as both tumors are intensely immunogenic (31).

Two isoenzymes regulate cortisol activity in the skin, activating and, respectively, inactivating it: $11-\beta$-hydroxysteroid dehydrogenase (11ßHSDH)1 and $2(32,58)$. In BCC, $11 \beta \mathrm{HSDH} 1$ is decreased, while its counterpart is increased (32). Of note, $11 \beta \mathrm{HSDH} 2$ is non-existent in healthy skin, but its expression is increased in proliferating basal cells in BCC and seborrheic keratosis (SK). One hypothesis is that local cortisol activation via $11 \beta \mathrm{HSDH} 1$ in keratinocytes plays a role in controlling local stress and repeated stimulation (32). 11ßHSDH1 levels are low in BCC regardless of tumor differentiation, and may in fact induce cellular proliferation (33). Inhibition of $11 \beta \mathrm{HSDH} 1$ has been reported to activate epidermal cells hyperproliferation in murine models (58). Moreover, Terao et al found that $11 \beta \mathrm{HSDH} 2$ was increased in BCC and SK, but not in SCC (33). According to these authors, 11ßHSDH1 and 2 may modulate intracellular glucocorticoid levels, subsequently influencing keratinocyte proliferation, differentiation and inflammation (33).

Chronic stress induces cellular mediated immune suppression (59), which plays a major role in NMSC-related tumoral surveillance. A reduction in the peritumoral CD4 lymphocyte population has been reported during chronic stress exposure, thus supporting the hypothesis according to which SCC susceptibility is mediated through the suppression of $\mathrm{T}$ cell activity $(60,61)$. Other studies have shown that long-term stress suppresses another tumor, eliminating NK cells, which leads to tumor metastasis in experimental models $(62,63)$.

Acute stress. As opposed to chronic stress, which acts as an immunosuppressant, acute stress reactions during immune activation or antigen exposure induce a redistribution of circulating immune cells towards organs, such as the skin, subcutaneous tissue and local lymph nodes $(59,64,65)$, thus enhancing both innate and acquired immunity $(59,65-70)$. This augmented immune response can also increase antitumoral activity against immunoresponsive malignancies, during tumoral immunotherapy or during surgery.

Due to the immunogenicity of SCC, studies have been carried out starting from the hypothesis that acute stress prior to UVR exposure would enhance the immune response and potentiate resistance to SCC development. Dhabhar et al (71) studied the immunomodulatory effects of short-term stress exposure in a murine model and found that the exposed to acute stress study group exhibited an increased expression of chemokine related genes, such as CTACK/CCL27, RANTES, IL-12 and IFN- $\gamma$ for up to 8 months, larger numbers of infiltrating $\mathrm{T}$ cells (both $\mathrm{CD}^{+}$and $\mathrm{CD}^{+}$) and a reduced SCC incidence at 4 months. These results suggest that acute stress increases chemokine gene expression and $\mathrm{T}$ cell trafficking following UVR exposure, while it also enhances cellular immunity.

Considering the relevance of these findings in relation to the discovery of novel mechanisms of antitumoral response activation, the intrinsic immune and non-immune mechanisms through which short-term stress during UVR exposure reduces future tumor burden need to be further elucidated.

\section{Neuroactive mediators}

Neurotransmitters. Whereas some studies suggest that neuroactive molecules influence the risk for developing malignancies (initiation phase), others have suggested that neuroactive compounds also affect progression, once disease is established.

Under stressful conditions, sympathetic nerve fibers release additional epinephrine and norepinephrine (NE), which have been previously shown to increase IL- 6 and reactive oxygen species production, thereby promoting cancer cell survival and proliferation (72,73). Moreover, in vitro studies have proven that cancer cell survival and proliferation can be successfully inhibited by incubation with adrenergic receptor (AR) antagonists $(74,75)$.

Following skin injury, basal keratinocytes migrate into the wound to initialize re-epithelialization, critical in wound repair and barrier function rehabilitation. Keratinocytes express high levels of $\beta$-ARs, without expressing other types of ARs, and they are also capable of synthesizing epinephrine $(76,77)$.

One explanation for the relative lack of studies and therefore knowledge in this particular area, is probably the difficulty in preserving and demonstrating neurotransmitter expression in cutaneous NMSC skin biopsies coupled with the inexistence of adequate antibodies for such conditions of fixation.

As early as the 1950's Winkelmann (78) reported the presence of nerve fibers in close proximity to BCC cells; however, this author did not believe in the existence of a solid functional association between these nerve fibers and BCC proliferation. Current evidence indicates that several tumor cell lines express $\beta$-ARs and that catecholamine hormones may influence tumorigenesis via these receptors (79-85). Catecholamines are able to modulate the expression of vascular endothelial growth factor (VEGF) and matrix metalloproteinases (MMPs); thus, they can regulate various facets of tumor progression, such as proliferation, angiogenesis and metastasis (79,86-89).

MMPs and tissue inhibitors of metalloproteinases (TIMPs) are known for their role in extracellular matrix remodelling in both physiological and pathological processes, and several cytokines possess the ability to influence their expression (90). When collagenolytic MMPs are activated, they degrade the peritumoral matrix, thereby aiding in BCC and SCC microenvironment remodelling (91). Yang and Eubank (92) studied the effect of neuroendocrine alteration on MMP and TIMP expression. Using a blister chamber wound model on UVB-exposed human forearm skin, they reported that the activation of the hypothalamic-pituitary-adrenal (HPA) and sympathetic-adrenal medullary (SAM) axes indeed modulate MMP levels. Their results revealed a positive correlation between NE plasma levels and MMP-2 levels, and a negative association between plasmatic cortisol levels and MMP-2 levels. These data indicate that the release of NE associated with the sympathetic nervous system can modulate MMP levels (93). Dumas et al (94) also reported an increased expression of MMP-9 and MMP-2 in SCC versus BCC, which in conjunction with the reduced expression of type IV collagen, led the authors to conclude that this could be a possible explanation to 
the significantly enhanced aggressive behavior of SCC when compared to BCC (95).

A recent study by Peterson et al investigated the role of the nervous system in somatic cancer (96). The authors examined the role of cutaneous nerve fibers in a model of spontaneous BCC following the genetic deletion of PTCH1 and found that tumors developed mainly in touch domes and bulge regions of hair follicles, although not in the interfollicular epidermis. In their study, they disclosed the presence of mRNA for the three hedgehog ligands in the dorsal root ganglia, the location of sensory neurons that project to the skin, and thus hypothesized that the loss of sensory-derived signaling mediators, which inhibit the hedgehog pathway may be a driving factor for carcinogenesis.

There is also evidence supporting the direct involvement of peripheral nerve fibers in cutaneous epithelial cell homeostasis in reports showing the progressive loss of Merkel cells following denervation $(97,98)$. BCC, an epidermal tumor, is also lined with Merkel cells.

In a previous study, PTCH1 wild-type mice had considerably fewer Merkel cells and significantly fewer tumor cells in touch dome-derived tumors in contrast to the sham-lesioned contralateral side, five weeks after denervation (96). Based on this observation, the authors suggested denervation as a potential therapeutic tool, not only for BCC, but also for Merkel cell malignancies (96). Nevertheless, other authors have suggested that, even though Merkel cell tumors display phenotypes similar to native Merkel cells, they still arise from skin stem cells, and as such are susceptible to influence from cutaneous innervation (99). The one compelling finding of this previous study was that surgical or chemical ablation of nerve fibers significantly reduced or slowed BCC progression.

Bernabé et al (72) examined the effects of stress hormones on SCC cell lines (SCC9, SCC15 and SCC25) and found that not only can stress-related mediators (NE and isoproterenol) enhance the production of the pro-angiogenic cytokine, IL-6, in these cell lines, but that these cells are also capable of producing IL- 6 by themselves and, without stimulation, these levels being already detectable at $1 \mathrm{~h}$. The authors noted that concentrations of IL-6 secreted by these cells, even by non-stimulated cells, are within the range expected to have biological activity. Similarly to the effects of IL-6 expression, in this study, treatment with NE at physiological stress levels $(10 \mu \mathrm{M})$ induced direct proliferation in SCC9 and SCC15 cell lines, demonstrating constitutive expression of $\beta 1$ - and $\beta 2$-ARs in the tested cell lines (72).

Another neurotransmitter-related enzyme, acetylcholinesterase $(\mathrm{AChE})$ is found in sites where acetylcholine (Ach) acts as a neurotransmitter (e.g., cholinergic synapses or myoneural junctions). Furthermore, this enzyme has frequently been used as a marker for Ach activity. Iyengar, demonstrated AChE activity on the melanocyte cell membrane in hyperpigmented skin lesions such as pigmented BCC and lichen planus (100), but the study did not associate AchE/Ach with any specific function or mechanism involved in carcinogenesis.

Neuropeptides. When skin is exposed to harmful stimuli, including UVR, the unmyelinated c-fibers and myelinated Ad-fibers of sensory nerves release various neuropeptides $(101,102)$, most importantly calcitonin gene-related peptide (CGRP), substance $\mathrm{P}$ (SP) $(103,104)$ and nerve growth factor (NGF), thereby initiating an inflammatory process comprising cutaneous vessel dilation, increased vascular permeability, plasmatic extravasation and edema $(105,106)$ which may promote tumorigenesis. The most important neuropeptides are discussed below:

i) Calcitonin gene-related peptide. CGRP is a 37-amino-acid neuropeptide which exists in two isoforms ( $a$ - and b-) differing by a single amino-acid, and is widely expressed in both the central and peripheral nervous systems (107). CGRP-containing nerve fibers in the skin are closely associated with LCs (108). Apart from being a potent vasodilator and immunomodulator, CGRP increases cAMP levels in T cells, participates in chemotaxis, inhibits proliferation, and inhibits the production of IL-2 and the expression of TNF- $\alpha$, TNF- $\beta$ and IFN- $\gamma$. It stimulates IL-10 and downregulates IL-1 $\beta$ expression in macrophages. Furthermore, it also impedes antigen presentation by LCs, as shown in murine models $(102,108,109)$, hindering a crucial step in anti-tumoral immune response initiation.

Studying the effects of UVB exposure on rat skin, Gillardon et al (110) demonstrated that an inflammatory dose of UVB caused the release of SP and CGRP from terminals of cutaneous sensory nerve fibers, leading to a temporary decrease in the skin's content of neuropeptides during the first 6 to $12 \mathrm{~h}$ following exposure. Nevertheless, as the authors pointed out, the level of CGRP increased again and the cutaneous content of CGRP exceeded the control levels at 48-72 h post-UVR exposure. This suggests an increase in the synthesis and transport of neuropeptides into the area of UVR-induced inflammation (111). Niizeki et al found similar immunosuppressive effects by intradermal injections of CGRP and acute UVR exposure, which could both be prevented by pre-treatment of mice with a specific CGRP antagonist, namely CGRP 8-37 (112). Furthermore, the authors reported a reduced number of cutaneous LCs after CGRP or UVR exposure. This suggests a possible impact in skin carcinogenesis (113).

During the identification of intracellular mechanisms significant for the transduction of the mitogenic message of neuropeptides, much of the research has focused on cAMP, mainly due to the demonstration of increased cAMP synthesis and its association with the early events following the mitogenic stimulation of various cell systems (114).

Takahashi et al (115) demonstrated the stimulation of cAMP formation by CGRP in an in vitro study using primary cultured normal human epidermal keratinocytes (NHEKs) and a human SCC cell line, HSC-1. The authors noted that CGRP induced a rapid and notable increase in the intracellular accumulation of cAMP in both cell lines. CGRP also significantly enhanced DNA synthesis and the growth of HSC-1 cells in a dose-dependent manner. Intriguingly, the increase in intracellular cAMP content following stimulation with CGRP was only 6-fold in the HSC-1 cell line compared to an 8-fold increase noted in the NHEKs. This result was attributed by the authors to different levels of receptors expressed on the cell membrane.

There are many conflicting in vivo and in vitro reports concerning the increase in the levels of cAMP in proliferating keratinocytes. Some authors have reported that the mediators increasing intracellular cAMP stimulate keratinocyte proliferation $(116,117)$, while others have observed an inhibitory effect of cAMP analogs on keratinocyte growth (118-122). It is 
important to take into account that none of the cAMP analogs or agents used to increase cAMP levels in those studies function specifically to increase intracellular cAMP levels (114). Thereby these results may be subjected to certain skepticism.

ii) Substance P. SP is an inflammatory molecule belonging to the tachykinin family, found in primary sensory neurons and afferent vagal sensory nerve fibers together with CGRP (123) Its cellular effects are mediated through neurokinin-1 receptor (NK1-R), NK2-R and NK3-R of which NK1-R has the highest binding affinity to SP (124). SP has been shown to be involved in local blood flow and vascular permeability. It induces lymphocyte proliferation and chemotaxis, increases immunoglobulin production, activates macrophages and favors the secretion of several pro-inflammatory cytokines, including IL-1, IL- 6 and TNF- $\alpha$. As a consequence, among other important processes, SP has been found to be involved in the regulation of sensorial perception and stress responses $(125,126)$.

Over the past few years, we have witnessed an increasing interest in the role of SP in tumor development and progression. Indeed, it has been identified as a potent mitogen for certain epithelial premalignant lesions and cancer cellular lines, such as melanoma, glioma, retinoblastoma and neuroblastoma (127-131). Hence, the SP/NK-1R system may have a role to play in NMSC development, since SP may indeed be a universal mitogen in NK-1R-expressing tumor cell types.

Staniek et al (132) noted that at high concentrations (104 and $105 \mathrm{M})$, SP was able to inhibit in vitro epidermal cell reaction responses by acting on LCs and T cells. As stated above, cutaneous sensory nerves contain SP and a considerable increase in SP immunoreactivity is detected following UVR exposure (133). Thus, there is indirect evidence suggesting that SP plays a role in UV-induced inflammatory reactions (134).

When SP binds to NK-1R, it activates certain members of the mitogen-activated protein kinase intracellular signaling cascade, including extracellular signal regulated kinases 1 and 2 (ERK 1/2). These molecules then translocate to the nucleus and induce cell proliferation and protect the cell from apoptosis (135).

Brener et al (136) investigated the presence and distribution of SP and NK-1R in SCC and their association with tumor proliferation. The authors demonstrated for the first time the expression of SP and NK-1R in SCC, and reported a strong expression of both proteins, particularly SP, in all tissue compartments of the analyzed tumor samples. They also reported a direct and significant correlation between SP and NK-1R expression in different tumor tissue compartments, thus suggesting that SP overexpression is accompanied by an increase in the expression of NK-1R molecules, a phenomenon also demonstrated by other authors (135).

According to Weinstock et al (137), SP can also stimulate cell proliferation through the transactivation of EGFR. The connection between these functions and the SP/NK-1R interactions has led some authors to suggest that SP/NK-1R may be associated with both cancer development and progression (135).

iii) Nitric oxide. Nitric oxide synthase (NOS) (along with CGRP and SP) is located in visceral afferent neurons in the lower thoracic tract dorsal root ganglion (138), and has been incriminated in neurogenic inflammation in murine models (139). This early observation led to the investigation of the effect of NOS on immunoreactivity in UVR-exposed skin and UV-induced vasodilation (134). In the study by Gillardon et al (110), it was concluded that NO released from nerve endings following UVR exposure promoted post-liminary local immune suppression. Moreover, the authors noted the far from negligible contribution of inducible NOS from activated macrophages and neutrophils. Indeed, the inducible form of NOS (iNOS) is the isoform most consistently associated with neoplasia. When produced by immune cells, iNOS in turn leads to the production of large amounts of NO, pivotal in pathogen defense responses, cytokine production and $\mathrm{T}$ helper lymphocyte expansion. On the other hand, the upregulation of iNOS has been characterized to act exclusively as a pathological mediator (140-145).

Rosbe et al (146) investigated the activity of NOS and the presence of NO in human SCC. They found iNOS activity in squamous epithelial cells throughout all the analyzed SCC tumor tissue, with the enzyme activity being highest in surrounding keratin pearls.

It has been found that iNOS is upregulated in cutaneous SCC (147), but is downregulated in skin BCC, probably contributing to the lack of aggressive features displayed by the latter (148).

NO production by SCC cells is consistent with other evidence that NO may be a promoter of local tumor growth and metastasis by enhancing neovascularization. In two separate studies, Andrade et al (149) and Maeda et al (150) found that NOS inhibitors were able to reduce tumor blood flow. The morphology and sensitivity to vasoactive agents of these newly formed blood vessels seemed to differ from vessels in normal tissue, possibly explaining the presence of iNOS instead of endothelial-NOS in mouse tumor capillaries.

Connelly et al (151) studied the expression of iNOS in tissue samples of SCC and compared them to samples of dysplasia and normal controls. They reported $95 \%$ staining in SCC, $50 \%$ in dysplasia and $0 \%$ in normal epithelial controls with positive staining for iNOS only in SCC cells. They also detected a significantly higher production of NO in SCC cells compared to control cells. Their results localized iNOS to SCC tumor cells, and not to the region of inflammation within the stroma, thereby suggesting that the malignant cells are the source of iNOS.

One study also found plasma levels of NO compounds in patients with BCC to be significantly increased when compared to controls (152). The authors hypothesized that increased plasma levels of NO in patients with BCC are the result of accentuated hyperkeratinization, hyperpigmentation, and keratinocyte proliferation and proposed that this increased production of NO may operate as a growth stimulator, having a potential mitogenic function, finally accelerating the proliferation of this type of NMSC cells (152).

NO may also play a role in tumor metastasis via the promotion of endothelial cell adhesion and vascular permeability (153). Even though it was hypothesized that tumor cells may use an iNOS-mediated mechanism to adhere to the vascular endothelium and further penetrate vessel walls, thus gaining access to distant sites, some authors (154) have found an inverse correlation between NO and metastasis. Therefore, the complete role of NO in cancer metastasis remains to be fully elucidated.

iv) Somatostatin (SST). SST was first identified in 1973 as a growth hormone release-inhibitor (155) with its main functions 
involving the regulation of exo- and endocrine secretions, the modulation of motor activity and the inhibition of gastrin-stimulated gastric acid secretion (156). Several recent studies have suggested that SST can act as a tumor suppressor gene, and perform significant antitumor and antisecretory activities in various human malignancies both in vivo and in vitro (156-158).

Through the inhibition of growth factors and hormones, the diminishing of vascularization and immune system regulation, SST seems capable of suppressing tumor growth in a variety of cancers $(159,160)$, including human pancreatic tumor cells (MIA PaCa-2), breast cancer cells (MCF-7) and small cell lung cancer cells (HCI-H69) (160-162). An epidermoid carcinoma cell line, A431, possesses a very high level of EGF receptors and exhibits an attenuation of cell proliferation in response to EGF (163). Mascardo and Sherline demonstrated rapid centrosomal separation and cell growth stimulation by EGF in mitogenically responsive cells (164).

Kamiya et al (165) examined the in vitro effects of SST-14 and its octapeptide analogue, SMS 201-995, on the growth of A431 cells. The authors found that both SS-14 and SMS 201-995 stimulated the growth of A431 cells, most probably affecting their inositolphosphatase metabolism. Moreover, these authors demonstrated the presence of high-affinity receptors for SS in A431 cells (165). Of note, SS-14 and SMS 201-995 initiated a stimulatory effect in KB cells, another line of epidermoid carcinoma cells, but not in the three tested squamous carcinoma cell lines, HSC-2, -3 and -4. Even though these cell lines resemble the A431 and KB cell lines, they responded with a decrease in cell growth. It was concluded that the growth regulatory mechanism in the respective cell lines differs with respect to SST or that HSC cells may lack SST receptors (165).

As evidenced from the above, it has been well established that neurogenic inflammation and other various alterations of the microenvironment create a milieu conducive to carcinogenesis. Intriguingly, stress alone can induce neurochemical changes that promote cell proliferation and carcinogenesis; however, there are also reports in which the use of other neuromodulators appears to create a tumor suppressive environment. This body of evidence thereby suggests that these neuroactive mediators affect the odds of developing skin cancers through their neuromodulatory effects.

Neurohormones. The skin's neuroendocrinological properties have been previously demonstrated, the cutaneous organ being capable of secreting thyroid-stimulating hormone, oxytocin, growth hormones, and corticotropin-releasing hormone (CRH) (32).

The proopiomelanocortin (POMC) gene codes for the synthesis of a protein known as POMC, a precursor polypeptide with 241 amino acid residues, which is then enzymatically cleaved into a variety of biologically active peptides with different functions throughout the body. Among these neuropeptides, are adrenocorticotropin (ACTH), $\beta$-lipotropin ( $\beta$-LPH), endorphins $(\alpha-, \beta-, \gamma$-endorphin) and melanotropins $[\alpha-, \beta$-, $\gamma$-melanocyte-stimulating hormone (MSH)] (166). These peptides bind to several proteins in various regions of the body, triggering the activation of several signaling pathways that control a number of important functions. It is worthwhile mentioning that the production of POMC is not limited to the pituitary gland, and it has been found in various other tissues, including the skin (167). More precisely, $\alpha-\mathrm{MSH}$ and ACTH can also be produced by keratinocytes (168).

The existence of a local stress response system in the skin, which is equivalent to the central HPA axis has been previously revealed (34,169-172). It has also been confirmed that locally synthesized CRH can activate local CRH receptors (CRHRs) $(34,172)$. The discovery of CRHR in the skin suggests a potential CRH-induced neuroendocrine cutaneous pathway (172-175).

There are studies performed almost 20 years ago, incriminating $\mathrm{CRH}-\mathrm{POMC}$ axis-related hormones in the pathology of malignant melanoma (MM), SCC and BCC alike (176-179). Several studies have also suggested that UVR, the main carcinogen involved in the pathogenesis of NMSC, is capable of inducing the expression of CRH-POMC axis-related neurohormones $(170,180,181)$. Simultaneously, following UVR exposure or metabolic alteration, corresponding receptors are upregulated, such as melanocortin (MC)-1 and MC-5. Most receptors of the MC-1 class, are located on the surface of keratinocytes, and recognize MSH and ACTH (182). MSH and ACTH act not only as skin pigmentation regulators, but also as immunosuppressors (183) through the inhibition of specific IL-1, TNF- $\alpha$ and IL-2 functions (184).

Kim et al (185) performed an immunohistochemical analysis of $\mathrm{CRH}, \mathrm{ACTH}$ and $\alpha-\mathrm{MSH}$ expression in specimens from normal skin, melanocytic naevi, SK, actinic keratoses (AK), Bowen's disease, cutaneous T cell lymphoma (CTCL), BCC, SCC and MM. They reported CRH, ACTH and $\alpha-\mathrm{MSH}$ expression only in the upper epidermal layers in the normal skin, melanocytic naevus, SK, AK, Bowen's disease and CTCL samples. The expression of these neurohormones was generally weak or undetectable in benign and precancerous lesions, in CTCL and in normal controls. However, in the same study, BCC samples exhibited an intermediate expression of $\mathrm{CRH}$ while MM (80\%) and SCC (70\%) samples exhibited a strong immunoreactivity for $\mathrm{CRH}$. It was thereby concluded that the CRH-POMC axis-related neurohormones strongly correlated with cutaneous malignancies, and that $\mathrm{CRH}$ appears to be a more specific biomarker for skin cancers when compared to ACTH or $\alpha$-MSH (185).

Luger et al (186) tested human normal keratinocytes (HNKs) and A431 cells for their capacity to release $\alpha$-MSH by stimulating these cells with either the tumor promoter phorbol myristate acetate (PMA), IL-1 or UVB radiation. The authors reported the spontaneous release of low amounts of $\alpha-\mathrm{MSH}$ by both HNK and A431 cells, which was significantly increased by stimulation with PMA, IL-1 or UVB. Indeed, $\alpha$-MSH production by epidermal cells occurred between 48 and $72 \mathrm{~h}$ following culture initiation and among several other tested cytokines, only IL-1P proved to be effective in stimulating $\alpha$-MSH production by epidermal cells. Moreover, $\alpha$-MSH derived from epidermal cells was proven to be biologically active (186). Their results also showed that upon stimulation, normal and malignant keratinocytes produced melanotropins able to suppress the production and activity of the immunomodulating cytokine, IFN- $\gamma$ (186).

Arbiser et al (187) reported in vitro endothelial cell chemotaxis stimulation and in vivo stimulation of tumor growth and angiogenesis by CRH acting through CRHR. As a result, the authors inferred that $\mathrm{CRH}$ directly stimulates angiogenesis 
via the CRHRs present on endothelial cells and suggested that the ectopic production of $\mathrm{CRH}$ in malignancies may promote angiogenesis.

These aspects underline the fact that CRH-POMC peptides directly participate in UV-related skin cancers. POMC peptides are produced in the skin under UVB stimulation, and therefore create a microenvironment favorable for NMSC progression $(177,188)$. Among the suggested mechanisms, authors have cited immunosuppression, the inhibition of antigen-presenting structures on keratinocytes, and cell proliferation (177). It is unknown whether CRH-POMC peptides initiate or simply promote skin cancer pathogenesis (185), but such peptides are most certainly associated with a higher rate of tumor growth (187).

\section{Cellular neuro-immune interactions}

Numerous interactions have been identified linking the nervous system to various immune cells, including mast cells, neutrophils, macrophages and T cells $(189,190)$. Mast cells however, appear to be the key players in modulating stress-induced cutaneous inflammatory reactions (38).

As early as the 1990s, it has been shown (191) that increased numbers of dermal mast cells highly correlate with UVR-induced immune suppression, aggravated by the fact that UVR exposure increases dermal mast cell density $(192,193)$. Ten years later, observational studies reported that high densities of mast cells correlate with a poor prognosis for various tumors, such as BCCs and SCCs, MM, colon cancer and lymphoma (194). There are in fact a number of studies that have shown mast cells to accumulate around skin cancers and create permissive microenvironments (26,195-197).

UVR exposure indirectly activates dermal mast cells, supposedly through the activation of cutaneous nerve fibers, which release mast cell-activating neuropeptides (198). Two mechanisms of mast cell activation by means of UVR exposure are proposed: first a photoinduced isomerization of a photo-receptor, trans-urocanic acid (UCA) and second LC antigen-presenting dysfunction $(188,199,200)$.

Thus, UCA is converted to cis-UCA in the stratum corneum $(195,196)$. Cis-UCA stimulates cutaneous sensory nerves to release neuropeptides (SP and CGRP) $(195,201)$ and therefore mast cell degranulation. The other mechanisms refer to LC antigen-presenting dysfunction due to ultrastructural modifications (195).

Furthermore, mast cell mediators function not only as stimulators of angiogenesis, but also as immunosuppressors and promoters of extracellular matrix destruction and mitosis $(195,202)$. Tumor-associated mast cells are recruited via chemokines released from tumor cells. BCCs release stem cell factor that binds to the tyrosine-kinase receptor c-kit on the mast cell surface, thereby increasing the mast cell numbers around the tumor (197), and subsequently increasing dendritic cells numbers, leading to angiogenesis and collagenesis. Higher numbers of mast cells have been reported around BCCs and melanomas than around SCCs; however, the reason for this remains unclear (195). Mast cells are recruited preferentially around BCCs, independent of inflammatory infiltrate, with higher numbers observed around more aggressive tumors (203). Moreover, patients with a history of sporadic BCC have a high number of mast cells in non-exposed skin, in contrast with control subjects (196). The factors that condition the number of peritumoral mast cells in BCC are unclear; however, it has been suggested that NGF, stem cell factor and VEGF may be involved (196,204). NGF also facilitates histamine release from mast cells (205). Histamine is a known key mediator of UVB-induced immunosuppression (196). It limits T helper-1 lymphocyte expansion, but not $\mathrm{T}$ helper-2 lymphocytes (206). It stimulates keratinocyte-produced prostaglandin E2 that disrupts a cytokinic balance favoring IL-10, an immunosuppressor, and IL-12 (207), an immunostimulant that can induce DNA repair after UV damage (208). It also increases the number of suppressor T lymphocytes that produce IL-10, leading to immunosuppression via the apoptosis of antigen-presenting cells (195). Prostaglandin E2 can further stimulate angiogenic factor release from mast cells (209). Creating a paracrine loop, histamine further stimulates keratinocytes to release NGF that in turn binds to mast cell surface to complete the circle (205).

Apart from histamine, mast cells secrete many other proangiogenic factors, such as heparin, TNF- $\alpha$, TGF- $\beta$, IL- 8 and VEGF. Peritumoral mast cells are a major source of VEGF, which leads to endothelial mitosis and vascular hyperpermeability. This in turn permits the extravasation of other pro-angiogenic factors in the extracellular matrix, and tumoral cytokines, such s TGF alpha, a mitogenic polypeptide (195). All these cytokines stimulate VEGF production further (210).

Angiogenesis must be supported by extracellular matrix remodelling. Thus, mast cells release tryptase and chymase, two serine proteases that initiate matrix degradation and turn over $(26,211)$. One study (211) showed that tryptase activity was increased $>2$-fold in BCCs, while chymase-positive cells exhibited partial enzymatic inactivity.

Some studies have reported a significant increase in dermal mast cell degranulation, in a number of SP immunoreactive nerve fibers and contacts between mast cells and these nerve fibers, due to stress exposure $(212,213)$. Stress-induced degranulation seems to be dependent on CRH, but probably also involves SP and neurotensin. As opposed to anaphylactic reactions, stress does not provoke an explosive mast cell degranulation, but acts in a more silent manner, primarily inducing intragranular changes (214). Căruntu et al (38) examined the effects of acute and chronic stress on mast cell degranulation in glabrous and hairy mouse skin. In their study, the authors reported an amplification of mast cell degranulation in hairy skin due to short-term stress exposure, effect that continued with prolonged exposure to stress. By comparison, in glabrous skin, although acute stress intensely stimulated mast cell degranulation, the phenomenon subsided gradually as exposure to stress persisted (38).

The crosstalk between mast cells and sensory nerve fibers by means of increased NGF, neuropeptides and various other mediators, in photo-damaged skin, may thus influence the higher prevalence of NMSCs in these individuals.

\section{Conclusion and perspectives}

In addition to the classic agents involved in the pathogenesis of NMSC, such as chronic UVR exposure, the thinning of the ozone layer through pollution, immunosuppression, an increased lifespan, PTCH gene mutations and fair skin, a large number of studies have incriminated various neuroactive factors in the 
pathogenesis of NMSC. Furthermore, it has become obvious that the intricate interaction between the peripheral nervous system and cutaneous target cells (e.g., leukocytes, LCs and mast cells) is mediated through locally released neuroendocrine factors including catecholamines, SP, CGRP, SST, and neurohormones such as POMC and its derived peptides, alpha-MSH and ACTH, all of which have been, at one time or another, the subject of scientific dispute as to their precise role in the pathogenesis of NMSC.

A key function of physiological mediators released in short-term stress reactions may be to ensure that the proper cells (e.g., leukocytes) are in the right place, at the right time, and that they are activated appropriately to be able to respond to the immune challenge posed by the stressor (e.g., pathogen invasion of the host and UVR). Acute stress modulates immune cell distribution as an adaptive response responsible for enhancing immune surveillance and increasing the immune system's capacity to respond to challenges in various compartments (skin, mucosa, and epithelial linings of the gastrointestinal and genito-urinary tracts) which constitute major defense barriers throughout the body. Thereby, the current body of evidence suggests that neurotransmitters and hormones released under acute stressful situations may increase immune surveillance and augment immune responses for potential or ongoing challenges.

Although acute stress seems to play a rather protective role in the context of carcinogenesis for the aforementioned reasons, chronic stress, acting through the plethora of neuropeptides, neurohormones and cytokines involved, leads to chronic immunosuppression and, as a result, promotes a favorable environment for NMSC carcinogenesis. Further studies are needed in order to elucidate the exact mechanisms mediating beneficial versus harmful effects of stress mediated through the skin's neuroendocrine system, in order to translate the findings from bench to bedside. This field of research is very important, considering that stress has become an ubiquitous aspect of life and even though chronic stress, acting through the nervous, endocrine and immune systems, is thought to be among the etiological factors of various skin diseases (including NMSCs), acute stress is a fundamental survival mechanism that may very well be harnessed for immunoprotection. Additional studies are also required to define the precise processes through which neuroactive molecules promote or inhibit cutaneous carcinogenesis, as this could lead to the development of more sophisticated and tailored treatment protocols, as well as open new perspectives in skin cancer research, including penile SCC, for which a paucity of specific data on the pathogenic role of neuroendocrine factors exists.

\section{Acknowledgements}

This study was partly supported by a grant PN-II-PTPCCA-2013-4-1407 (Project 190/2014) financed by the Executive Agency for Higher Education, Research, Development and Innovation and by Young Researchers Grant 33891/2014 financed by 'Carol Davila' University of Medicine and Pharmacy, Bucharest, Romania.

\section{References}

1. Freedberg IM, Eisen AZ, Wolff K, Austen KF, Goldsmith LA and Katz S (eds): Fitzpatrick's Dermatology in general medicine. 6th edition. McGraw-Hil, New York, NY, 2003.
2. Rubin AI, Chen EH and Ratner D: Basal-cell carcinoma. N Engl J Med 353: 2262-2269, 2005.

3. Stern RS: Prevalence of a history of skin cancer in 2007: Results of an incidence-based model. Arch Dermatol 146: 279-282, 2010.

4. Rogers HW, Weinstock MA, Harris AR, Hinckley MR, Feldman SR, Fleischer AB and Coldiron BM: Incidence estimate of nonmelanoma skin cancer in the United States, 2006. Arch Dermatol 146: 283-287, 2010.

5. Diffey BL and Langtry JA: Skin cancer incidence and the ageing population. Br J Dermatol 153: 679-680, 2005.

6. Lanoue J and Goldenberg G: Basal cell carcinoma: A comprehensive review of existing and emerging nonsurgical therapies. J Clin Aesthet Dermatol 9: 26-36, 2016.

7. Renaud-Vilmer C and Basset-Seguin N: Basal cell carcinomas. Rev Prat 64: 37-44, 2014 (In French).

8. Alam M and Ratner D: Cutaneous squamous-cell carcinoma. N Engl J Med 344: 975-983, 2001.

9. Ch'ng S, Maitra A, Lea R, Brasch H and Tan ST: Parotid metastasis - an independent prognostic factor for head and neck cutaneous squamous cell carcinoma. J Plast Reconstr Aesthet Surg 59: 1288-1293, 2006.

10. Johnson TM, Rowe DE, Nelson BR and Swanson NA: Squamous cell carcinoma of the skin (excluding lip and oral mucosa). J Am Acad Dermatol 26: 467-484, 1992.

11. Rowe DE, Carroll RJ and Day CL Jr: Prognostic factors for local recurrence, metastasis, and survival rates in squamous cell carcinoma of the skin, ear, and lip. Implications for treatment modality selection. J Am Acad Dermatol 26: 976-990, 1992.

12. Rudolph R and Zelac DE: Squamous cell carcinoma of the skin. Plast Reconstr Surg 114: 82e-94e, 2004.

13. Weinberg AS, Ogle CA and Shim EK: Metastatic cutaneous squamous cell carcinoma: An update. Dermatol Surg 33: 885-899, 2007.

14. Siegel RL, Miller KD and Jemal A: Cancer statistics, 2016. CA Cancer J Clin 66: 7-30, 2016.

15. Hakenberg OW, Compérat EM, Minhas S, Necchi A, Protzel C and Watkin N; European Association of Urology: EAU guidelines on penile cancer: 2014 update. Eur Urol 67: 142-150, 2015.

16. Spiess PE, Dhillon J, Baumgarten AS, Johnstone PA and Giuliano AR: Pathophysiological basis of human papillomavirus in penile cancer: Key to prevention and delivery of more effective therapies. CA Cancer J Clin 66: 481-495, 2016.

17. Cakir BÖ, Adamson P and Cingi C: Epidemiology and economic burden of nonmelanoma skin cancer. Facial Plast Surg Clin North Am 20: 419-422, 2012.

18. Kayes O, Ahmed HU, Arya M and Minhas S: Molecular and genetic pathways in penile cancer. Lancet Oncol 8: 420-429, 2007.

19. Protzel C and Spiess PE: Molecular research in penile cancer-lessons learned from the past and bright horizons of the future? Int J Mol Sci 14: 19494-19505, 2013.

20. Berton TR, Pavone A and Fischer SM: Ultraviolet-B irradiation alters the cell cycle machinery in murine epidermis in vivo. J Invest Dermatol 117: 1171-1178, 2001.

21. Oberyszyn TM: Non-melanoma skin cancer: Importance of gender, immunosuppressive status and vitamin D. Cancer Lett 261: 127-136, 2008.

22. Voiculescu V, Calenic B, Ghita M, Lupu M, Caruntu A, Moraru L, Voiculescu S, Ion A, Greabu M, Ishkitiev N, et al: From normal skin to squamous cell carcinoma: A quest for novel biomarkers. Dis Markers 2016: 4517492, 2016.

23. Ratushny V, Gober MD, Hick R, Ridky TW and Seykora JT: From keratinocyte to cancer: The pathogenesis and modeling of cutaneous squamous cell carcinoma. J Clin Invest 122: 464-472, 2012.

24. Stockfleth E, Ortonne JP and Alomar A: Actinic keratosis and field cancerisation. Eur J Dermatol 21 (Supp 1): 3-11, 2011.

25. Lugović L, Situm M, Vurnek M and Buljan M: Influence of psychoneuroimmunologic factors on patients with malignant skin diseases. Acta Med Croatica 61: 383-389, 2007 (In Croatian).

26. Leon A, Ceauşu Z, Ceauşu M, Ardeleanu C and Mehedinţi R: Mast cells and dendritic cells in basal cell carcinoma. Rom J Morphol Embryol 50: 85-90, 2009.

27. Calenic B, Greabu M, Caruntu C, Tanase C and Battino M: Oral keratinocyte stem/progenitor cells: Specific markers, molecular signaling pathways and potential uses. Periodontol 2000 69: 68-82, 2015.

28. Neagu M, Caruntu C, Constantin C, Boda D, Zurac S, Spandidos DA and Tsatsakis AM: Chemically induced skin carcinogenesis: Updates in experimental models (Review). Oncol Rep 35: 2516-2528, 2016. 
29. Neagu M, Constantin C, Dumitrascu GR, Lupu AR, Caruntu C, Boda D and Zurac S: Inflammation markers in cutaneous melanoma - edgy biomarkers for prognosis. Discoveries 3: e38, 2015.

30. Fagundes CP, Glaser R, Johnson SL, Andridge RR, Yang EV, Di Gregorio MP, Chen M, Lambert DR, Jewell SD, Bechtel MA, et al: Basal cell carcinoma: Stressful life events and the tumor environment. Arch Gen Psychiatry 69: 618-626, 2012.

31. Saul AN, Oberyszyn TM, Daugherty C, Kusewitt D, Jones S, Jewell S, Malarkey WB, Lehman A, Lemeshow S and Dhabhar FS: Chronic stress and susceptibility to skin cancer. J Natl Cancer Inst 97: 1760-1767, 2005.

32. Terao M and Katayama I: Local cortisol/corticosterone activation in skin physiology and pathology. J Dermatol Sci 84: 11-16, 2016.

33. Terao M, Itoi $S$, Murota $H$ and Katayama I: Expression profiles of cortisol-inactivating enzyme, $11 \beta$-hydroxysteroid dehydrogenase-2, in human epidermal tumors and its role in keratinocyte proliferation. Exp Dermatol 22: 98-101, 2013.

34. Slominski A and Wortsman J: Neuroendocrinology of the skin. Endocr Rev 21: 457-487, 2000

35. Slominski A: Neuroendocrine system of the skin. Dermatology 211: 199-208, 2005.

36. Zmijewski MA and Slominski AT: Neuroendocrinology of the skin: An overview and selective analysis. Dermatoendocrinol 3: 3-10, 2011

37. Căruntu C, Grigore C, Căruntu A, Diaconeasa A and Boda D: The role of stress in skin diseases. Intern Med 8: 73-84, 2011.

38. Căruntu C, Boda D, Musat S, Căruntu A and Mandache E: Stress-induced mast cell activation in glabrous and hairy skin. Mediators Inflamm 2014: 105950, 2014.

39. Căruntu C, Boda D, Musat S, Căruntu A, Poenaru E, Calenic B, Savulescu-Fiedler I, Draghia A, Rotaru M and Badarau AI: Stress effects on cutaneous nociceptive nerve fibers and their neurons of origin in rats. Rom Biotechnol Lett 19: 9518, 2014.

40. Arck P and Paus R: From the brain-skin connection: The neuroendocrine-immune misalliance of stress and itch. Neuroimmunomodulation 13: 347-356, 2006.

41. Gupta MA and Gupta AK: Psychiatric and psychological co-morbidity in patients with dermatologic disorders: Epidemiology and management. Am J Clin Dermatol 4: 833-842, 2003.

42. Căruntu C, Ghita MA, Căruntu A and Boda D: The role of stress in the multifactorial etiopathogenesis of acne. Ro Med J 58 98-101, 2011.

43. Sinnya S and De'Ambrosis B: Stress and melanoma: Increasing the evidence towards a causal basis. Arch Dermatol Res 305 851-856, 2013

44. Sanzo M, Colucci R, Arunachalam M, Berti S and Moretti S: Stress as a possible mechanism in melanoma progression. Dermatol Res Pract 2010: 483493, 2010

45. de Vries E, Trakatelli M, Kalabalikis D, Ferrandiz L, Ruiz-de-Casas A, Moreno-Ramirez D, Sotiriadis D, Ioannides D, Aquilina S, Apap C, et al; EPIDERM Group: Known and potential new risk factors for skin cancer in European populations: A multicentre case-control study. Br J Dermatol 167 (Suppl 2): 1-13, 2012.

46. Bulman A, Neagu M and Constantin C: Immunomics in skin cancer - improvement in diagnosis, prognosis and therapy monitoring. Curr Proteomics 10: 202-217, 2013.

47. Parker J, Klein SL, McClintock MK, Morison WL, Ye X, Conti CJ, Peterson N, Nousari CH and Tausk FA: Chronic stress accelerates ultraviolet-induced cutaneous carcinogenesis. J Am Acad Dermatol 51: 919-922, 2004.

48. Reiss Y, Proudfoot AE, Power CA, Campbell JJ and Butcher EC: $\mathrm{CC}$ chemokine receptor (CCR) 4 and the CCR10 ligand cutaneous T cell-attracting chemokine (CTACK) in lymphocyte trafficking to inflamed skin. J Exp Med 194: 1541-1547, 2001.

49. Dighe AS, Richards E, Old LJ and Schreiber RD: Enhanced in vivo growth and resistance to rejection of tumor cells expressing dominant negative IFN $\gamma$ receptors. Immunity 1 : 447-456, 1994

50. Voest EE, Kenyon BM, O'Reilly MS, Truitt G, D'Amato RJ and Folkman J: Inhibition of angiogenesis in vivo by interleukin 12 J Natl Cancer Inst 87: 581-586, 1995.

51. Shankaran V, Ikeda H, Bruce AT, White JM, Swanson PE, Old LJ and Schreiber RD: IFNgamma and lymphocytes prevent primary tumour development and shape tumour immunogenicity. Nature 410: 1107-1111, 2001.

52. Sephton SE, Dhabhar FS, Classen C and Spiegel D: The diurnal cortisol slope as a predictor of immune reactivity to interpersonal stress. Brain Behav Immun 14: 128, 2000.
53. Mormont MC and Lévi F: Circadian-system alterations during cancer processes: A review. Int J Cancer 70: 241-247, 1997.

54. Filipski E, King VM, Li X, Granda TG, Mormont MC, Liu X, Claustrat B, Hastings MH and Lévi F: Host circadian clock as a control point in tumor progression. J Natl Cancer Inst 94: 690-697, 2002

55. Fu L and Lee CC: The circadian clock: Pacemaker and tumour suppressor. Nat Rev Cancer 3: 350-361, 2003.

56. Sephton SE, Sapolsky RM, Kraemer HC and Spiegel D: Early mortality in metastatic breast cancer patients with absent or abnormal diurnal cortisol rhythms. J Natl Cancer Inst 92: 994-1000, 2000.

57. Wong CS, Strange RC and Lear JT: Basal cell carcinoma. BMJ 327: 794-798, 2003.

58. Terao M, Murota H, Kimura A, Kato A, Ishikawa A, Igawa K, Miyoshi E and Katayama I: 11 $\beta$-Hydroxysteroid dehydrogenase-1 is a novel regulator of skin homeostasis and a candidate target for promoting tissue repair. PLoS One 6: e25039, 2011.

59. Dhabhar FS and McEwen BS: Acute stress enhances while chronic stress suppresses cell-mediated immunity in vivo: A potential role for leukocyte trafficking. Brain Behav Immun 11: 286-306, 1997.

60. Kripke ML: Ultraviolet radiation and immunology: Something new under the sun - presidential address. Cancer Res 54: 6102-6105, 1994

61. Granstein RD and Matsui MS: UV radiation-induced immunosuppression and skin cancer. Cutis 74 (Suppl): 4-9, 2004.

62. Ben-Eliyahu S, Yirmiya R, Liebeskind JC, Taylor AN and Gale RP: Stress increases metastatic spread of a mammary tumor in rats: Evidence for mediation by the immune system. Brain Behav Immun 5: 193-205, 1991.

63. Ben-Eliyahu $\mathrm{S}$ : The promotion of tumor metastasis by surgery and stress: Immunological basis and implications for psychoneuroimmunology. Brain Behav Immun 17 (Suppl 1): S27-S36, 2003.

64. Dhabhar FS, Miller AH, McEwen BS and Spencer RL: Effects of stress on immune cell distribution. Dynamics and hormonal mechanisms. J Immunol 154: 5511-5527, 1995.

65. Dhabhar FS, Miller AH, McEwen BS and Spencer RL: Stress-induced changes in blood leukocyte distribution. Role of adrenal steroid hormones. J Immunol 157: 1638-1644, 1996.

66. Dhabhar FS and McEwen BS: Enhancing versus suppressive effects of stress hormones on skin immune function. Proc Natl Acad Sci USA 96: 1059-1064, 1999.

67. Dhabhar FS and Viswanathan K: Short-term stress experienced at time of immunization induces a long-lasting increase in immunologic memory. Am J Physiol Regul Integr Comp Physiol 289: R738-R744, 2005.

68. Saint-Mezard P, Chavagnac C, Bosset S, Ionescu M, Peyron E, Kaiserlian D, Nicolas JF and Bérard F: Psychological stress exerts an adjuvant effect on skin dendritic cell functions in vivo. J Immunol 171: 4073-4080, 2003.

69. Viswanathan K, Daugherty C and Dhabhar FS: Stress as an endogenous adjuvant: Augmentation of the immunization phase of cell-mediated immunity. Int Immunol 17: 1059-1069, 2005.

70. Wood PG, Karol MH, Kusnecov AW and Rabin BS: Enhancement of antigen-specific humoral and cell-mediated immunity by electric footshock stress in rats. Brain Behav Immun 7: 121-134, 1993.

71. Dhabhar FS, Saul AN, Daugherty C, Holmes TH, Bouley DM and Oberyszyn TM: Short-term stress enhances cellular immunity and increases early resistance to squamous cell carcinoma. Brain Behav Immun 24: 127-137, 2010.

72. Bernabé DG, Tamae AC, Biasoli ÉR and Oliveira SHP: Stress hormones increase cell proliferation and regulates interleukin-6 secretion in human oral squamous cell carcinoma cells. Brain Behav Immun 25: 574-583, 2011.

73. Lackovicova L, Banovska L, Bundzikova J, Janega P, Bizik J, Kiss A and Mravec B: Chemical sympathectomy suppresses fibrosarcoma development and improves survival of tumor-bearing rats. Neoplasma 58: 424-429, 2011

74. Coelho M, Moz M, Correia G, Teixeira A, Medeiros R and Ribeiro L: Antiproliferative effects of $\beta$-blockers on human colorectal cancer cells. Oncol Rep 33: 2513-2520, 2015.

75. Liou SF, Lin HH, Liang JC, Chen IJ and Yeh JL: Inhibition of human prostate cancer cells proliferation by a selective alpha1-adrenoceptor antagonist labedipinedilol-A involves cell cycle arrest and apoptosis. Toxicology 256: 13-24, 2009.

76. Schallreuter KU, Lemke KR, Pittelkow MR, Wood JM, Körner C and Malik R: Catecholamines in human keratinocyte differentiation. J Invest Dermatol 104: 953-957, 1995. 
77. Pullar CE, Rizzo A and Isseroff RR: beta-Adrenergic receptor antagonists accelerate skin wound healing: Evidence for a catecholamine synthesis network in the epidermis. J Biol Chem 281: 21225-21235, 2006

78. Winkelmann RK: Cutaneous nerves in relation to epithelial tumors. J Invest Dermatol 27: 273-279, 1956.

79. Lutgendorf SK, Cole S, Costanzo E, Bradley S, Coffin J, Jabbari S, Rainwater K, Ritchie JM, Yang M and Sood AK: Stress-related mediators stimulate vascular endothelial growth factor secretion by two ovarian cancer cell lines. Clin Cancer Res 9: 4514-4521, 2003.

80. Lutgendorf SK, Johnsen EL, Cooper B, Anderson B, Sorosky JI, Buller RE and Sood AK: Vascular endothelial growth factor and social support in patients with ovarian carcinoma. Cancer 95: $808-815,2002$

81. Roy R, Zhang B and Moses MA: Making the cut: Protease-mediated regulation of angiogenesis. Exp Cell Res 312: 608-622, 2006

82. Sood AK, Bhatty R, Kamat AA, Landen CN, Han L, Thaker PH, Li Y, Gershenson DM, Lutgendorf S and Cole SW: Stress hormone-mediated invasion of ovarian cancer cells. Clin Cancer Res 12: 369-375, 2006.

83. Tammela T, Enholm B, Alitalo K and Paavonen K: The biology of vascular endothelial growth factors. Cardiovasc Res 65 $550-563,2005$

84. Tas F, Oguz H, Argon A, Duranyildiz D, Camlica H, Yasasever V and Topuz E: The value of serum levels of IL-6, TNF-alpha, and erythropoietin in metastatic malignant melanoma: Serum IL-6 level is a valuable prognostic factor at least as serum LDH in advanced melanoma. Med Oncol 22: 241-246, 2005.

85. Ugurel S, Rappl G, Tilgen W and Reinhold U: Increased serum concentration of angiogenic factors in malignant melanoma patients correlates with tumor progression and survival. J Clin Oncol 19: 577-583, 2001.

86. Al-Wadei HAN, Plummer HK III and Schuller HM: Nicotine stimulates pancreatic cancer xenografts by systemic increase in stress neurotransmitters and suppression of the inhibitory neurotransmitter gamma-aminobutyric acid. Carcinogenesis 30: 506-511, 2009

87. Schuller HM, Al-Wadei HAN, Ullah MF and Plummer HK III: Regulation of pancreatic cancer by neuropsychological stress responses: A novel target for intervention. Carcinogenesis 33 191-196, 2012

88. Yang EV, Sood AK, Chen M, Li Y, Eubank TD, Marsh CB Jewell S, Flavahan NA, Morrison C, Yeh PE, et al: Norepinephrine up-regulates the expression of vascular endothelial growth factor, matrix metalloproteinase (MMP)-2, and MMP-9 in nasopharyngeal carcinoma tumor cells. Cancer Res 66: 10357-10364, 2006.

89. Zhang D, Ma QY, Hu HT and Zhang M: $\beta 2$-adrenergic antagonists suppress pancreatic cancer cell invasion by inhibiting CREB, NFкB and AP-1. Cancer Biol Ther 10: 19-29, 2010.

90. Zurac S, Neagu M, Constantin C, Cioplea M, Nedelcu R, Bastian A, Popp C, Nichita L, Andrei R, Tebeica T, et al: Variations in the expression of TIMP1, TIMP2 and TIMP3 in cutaneous melanoma with regression and their possible function as prognostic predictors. Oncol Lett 11: 3354-3360, 2016.

91. Yucel T, Mutnal A, Fay K, Fligiel SE, Wang T, Johnson T, Baker SR and Varani J: Matrix metalloproteinase expression in basal cell carcinoma: Relationship between enzyme profile and collagen fragmentation pattern. Exp Mol Pathol 79: 151-160, 2005.

92. Yang EV and Eubank TD: The impact of adrenergic signaling in skin cancer progression: Possible repurposing of $\beta$-blockers for treatment of skin cancer. Cancer Biomark 13: 155-160, 2013.

93. Yang EV, Bane CM, MacCallum RC, Kiecolt-Glaser JK, Malarkey WB and Glaser R: Stress-related modulation of matrix metalloproteinase expression. J Neuroimmunol 133: 144-150, 2002.

94. Dumas V, Kanitakis J, Charvat S, Euvrard S, Faure M and Claudy A: Expression of basement membrane antigens and matrix metalloproteinases 2 and 9 in cutaneous basal and squamous cell carcinomas. Anticancer Res 19 (4B): 2929-2938, 1999.

95. Lupu M, Caruntu C, Ghita MA, Voiculescu V, Voiculescu S, Rosca AE, Caruntu A, Moraru L, Popa IM, Calenic B, et al: Gene expression and proteome analysis as sources of biomarkers in basal cell carcinoma. Dis Markers 2016: 9831237, 2016.

96. Peterson SC, EberlM, Vagnozzi AN, Belkadi A, VeniaminovaNA, Verhaegen ME, Bichakjian CK, Ward NL, Dlugosz AA and Wong SY: Basal cell carcinoma preferentially arises from stem cells within hair follicle and mechanosensory niches. Cell Stem Cell 16: 400-412, 2015
97.English KB, Kavka-Van Norman D and Horch K: Effects of chronic denervation in type I cutaneous mechanoreceptors (Haarscheiben). Anat Rec 207: 79-88, 1983.

98. Nurse CA, Macintyre L and Diamond J: A quantitative study of the time course of the reduction in Merkel cell number within denervated rat touch domes. Neuroscience 11: 521-533, 1984

99. Tilling T and Moll I: Which are the cells of origin in merkel cell carcinoma? J Skin Cancer 2012: 680410, 2012.

100. Iyengar B: Modulation of melanocytic activity by acetylcholine Acta Anat (Basel) 136: 139-141, 1989.

101. Scholzen T, Armstrong CA, Bunnett NW, Luger TA, Olerud JE and Ansel JC: Neuropeptides in the skin: Interactions between the neuroendocrine and the skin immune systems. Exp Dermatol 7: 81-96, 1998

102. Seiffert K and Granstein RD: Neuropeptides and neuroendocrine hormones in ultraviolet radiation-induced immunosuppression. Methods 28: 97-103, 2002.

103. Holzer P: Local effector functions of capsaicin-sensitive sensory nerve endings: Involvement of tachykinins, calcitonin gene-related peptide and other neuropeptides. Neuroscience 24 : 739-768, 1988 .

104.Richardson JD and Vasko MR: Cellular mechanisms of neurogenic inflammation. J Pharmacol Exp Ther 302: 839-845, 2002

105. Roosterman D, Goerge T, Schneider SW, Bunnett NW and Steinhoff M: Neuronal control of skin function: The skin as a neuroimmunoendocrine organ. Physiol Rev 86: 1309-1379, 2006.

106. Căruntu C and Boda D: Evaluation through in vivo reflectance confocal microscopy of the cutaneous neurogenic inflammatory reaction induced by capsaicin in human subjects. J Biomed Opt 17: 085003, 2012

107.Zaidi M, Moonga BS, Bevis PJ, Bascal ZA and Breimer LH: The calcitonin gene peptides: Biology and clinical relevance. Crit Rev Clin Lab Sci 28: 109-174, 1990.

108. Hosoi J, Murphy GF, Egan CL, Lerner EA, Grabbe S, Asahina A and Granstein RD: Regulation of Langerhans cell function by nerves containing calcitonin gene-related peptide. Nature 363 . $159-163,1993$

109. Asahina A, Hosoi J, Grabbe S and Granstein RD: Modulation of Langerhans cell function by epidermal nerves. J Allergy Clin Immunol 96: 1178-1182, 1995.

110. Gillardon F, Moll I, Michel S, Benrath J, Weihe E and Zimmermann M: Calcitonin gene-related peptide and nitric oxide are involved in ultraviolet radiation-induced immunosuppression. Eur J Pharmacol 293: 395-400, 1995.

111. Seike M, Ikeda M, Morimoto A, Matsumoto M and Kodama H: Increased synthesis of calcitonin gene-related peptide stimulates keratinocyte proliferation in murine UVB-irradiated skin. J Dermatol Sci 28: 135-143, 2002.

112. Niizeki H, Alard P and Streilein JW: Calcitonin gene-related peptide is necessary for ultraviolet B-impaired induction of contact hypersensitivity. J Immunol 159: 5183-5186, 1997.

113. Legat FJ and Wolf P: Photodamage to the cutaneous sensory nerves: Role in photoaging and carcinogenesis of the skin? Photochem Photobiol Sci 5: 170-176, 2006.

114. Sjöholm A: Intracellular signal transduction pathways that control pancreatic $\beta$-cell proliferation. FEBS Lett 311: 85-90, 1992.

115. Takahashi K, Nakanishi S and Imamura S: Direct effects of cutaneous neuropeptides on adenylyl cyclase activity and proliferation in a keratinocyte cell line: Stimulation of cyclic AMP formation by CGRP and VIP/PHM, and inhibition by NPY through $\mathrm{G}$ protein-coupled receptors. J Invest Dermatol 101 646-651, 1993

116. Green H: Terminal differentiation of cultured human epidermal cells. Cell 11: 405-416, 1977.

117. Green H: Cyclic AMP in relation to proliferation of the epidermal cell: A new view. Cell 15: 801-811, 1978.

118. Yoshikawa K, Takeda J, Nemoto O, Halprin KM and Adachi K: Activation of cAMP-dependent protein kinase in epidermis by the compounds which increase epidermal cAMP. J Invest Dermatol 77: 397-401, 1981

119. Elgjo K: Epidermal chalone and cyclic AMP: An in vivo study. J Invest Dermatol 64: 14-18, 1975

120.Delecluse C, Fukuyama K and Epstein WL: Dibutyryl cyclic AMP-induced differentiation of epidermal cells in tissue culture. J Invest Dermatol 66: 8-13, 1976.

121. Voorhees JJ, Duell EA and Kelsey WH: Dibutyryl cyclic AMP inhibition of epidermal cell division. Arch Dermatol 105: 384-386, 1972. 
122. Marks F and Grimm W: Diurnal fluctuation and -adrenergic elevation of cyclic AMP in mouse epidermis in vivo. Nat New Biol 240: 178-179, 1972.

123. Wiesenfeld-Hallin Z, Hökfelt T, Lundberg JM, Forssmann WG, Reinecke M, Tschopp FA and Fischer JA: Immunoreactive calcitonin gene-related peptide and substance $P$ coexist in sensory neurons to the spinal cord and interact in spinal behavioral responses of the rat. Neurosci Lett 52: 199-204, 1984

124. Regoli D, Boudon A and Fauchére JL: Receptors and antagonists for substance P and related peptides. Pharmacol Rev 46 : 551-599, 1994.

125. Bang R, Sass G, Kiemer AK, Vollmar AM, Neuhuber WL and Tiegs G: Neurokinin-1 receptor antagonists CP-96,345 and L-733,060 protect mice from cytokine-mediated liver injury. J Pharmacol Exp Ther 305: 31-39, 2003.

126. Catalioto RM, Criscuoli M, Cucchi P, Giachetti A, Gianotti D, Giuliani S, Lecci A, Lippi A, Patacchini R, Quartara L, et al: MEN 11420 (Nepadutant), a novel glycosylated bicyclic peptide tachykinin NK2 receptor antagonist. Br J Pharmacol 123: 81-91, 1998.

127.Esteban F, Muñoz M, González-Moles MA and Rosso M: A role for substance $P$ in cancer promotion and progression: A mechanism to counteract intracellular death signals following oncogene activation or DNA damage. Cancer Metastasis Rev 25: 137-145, 2006.

128. Muñoz M, Pérez A, Coveñas R, Rosso $M$ and Castro E: Antitumoural action of L-733,060 on neuroblastoma and glioma cell lines. Arch Ital Biol 142: 105-112, 2004.

129. Muñoz M, Rosso M, Pérez A, Coveñas R, Rosso R, Zamarriego C and Piruat JI: The NK1 receptor is involved in the antitumoura action of L-733,060 and in the mitogenic action of substance $\mathrm{P}$ on neuroblastoma and glioma cell lines. Neuropeptides 39: 427-432, 2005.

130.González Moles MA, Mosqueda-Taylor A, Esteban F, Gil-Montoya JA, Díaz-Franco MA, Delgado M and Muñoz M Cell proliferation associated with actions of the substance $\mathrm{P} / \mathrm{NK}-1$ receptor complex in keratocystic odontogenic tumours. Ora Oncol 44: 1127-1133, 2008.

131. González Moles MA, Esteban F, Ruiz-Ávila I, Gil Montoya JA Brener S, Bascones-Martínez A and Muñoz M: A role for the substance P/NK-1 receptor complex in cell proliferation and apoptosis in oral lichen planus. Oral Dis 15: 162-169, 2009.

132. Staniek V, Misery L, Péguet-Navarro J, Abello J, Doutremepuich JD, Claudy A and Schmitt D: Binding and in vitro modulation of human epidermal Langerhans cell functions by substance P. Arch Dermatol Res 289: 285-291, 1997.

133. Eschenfelder CC, Benrath J, Zimmermann M and Gillardon F: Involvement of substance $\mathrm{P}$ in ultraviolet irradiation-induced inflammation in rat skin. Eur J Neurosci 7: 1520-1526, 1995

134. Benrath J, Eschenfelder C, Zimmerman M and Gillardon F: Calcitonin gene-related peptide, substance $\mathrm{P}$ and nitric oxide are involved in cutaneous inflammation following ultraviolet irradiation. Eur J Pharmacol 293: 87-96, 1995.

135. Koon HW, Zhao D, Na X, Moyer MP and Pothoulakis C: Metalloproteinases and transforming growth factor-alpha mediate substance P-induced mitogen-activated protein kinase activation and proliferation in human colonocytes. J Biol Chem 279: 45519-45527, 2004.

136. Brener S, González-Moles MA, Tostes D, Esteban F, Gil-Montoya JA, Ruiz-Avila I, Bravo M and Muñoz M: A role for the substance P/NK-1 receptor complex in cell proliferation in oral squamous cell carcinoma. Anticancer Res 29: 2323-2329, 2009.

137. Weinstock JV, Blum A, Walder J and Walder R: Eosinophils from granulomas in murine schistosomiasis mansoni produce substance P. J Immunol 141: 961-966, 1988.

138. Vincent SR and Hope BT: Neurons that say NO. Trends Neurosci 15: 108-113, 1992.

139. Lippe IT, Stabentheiner A and Holzer P: Participation of nitric oxide in the mustard oil-induced neurogenic inflammation of the rat paw skin. Eur J Pharmacol 232: 113-120, 1993.

140. Gallo O, Masini E, Morbidelli L, Franchi A, Fini-Storchi I, Vergari WA and Ziche M: Role of nitric oxide in angiogenesis and tumor progression in head and neck cancer. J Natl Cance Inst 90: 587-596, 1998.

141. Thomsen LL, Lawton FG, Knowles RG, Beesley JE, Riveros-Moreno V and Moncada S: Nitric oxide synthase activity in human gynecological cancer. Cancer Res 54: 1352-1354, 1994.
142. Thomsen LL, Miles DW, Happerfield L, Bobrow LG, Knowles RG and Moncada S: Nitric oxide synthase activity in human breast cancer. Br J Cancer 72: 41-44, 1995.

143. Nathan C: Inducible nitric oxide synthase: what difference does it make? J Clin Invest 100: 2417-2423, 1997.

144. Song ZJ, Gong P and Wu YE: Relationship between the expression of iNOS, VEGF, tumor angiogenesis and gastric cancer. World J Gastroenterol 8: 591-595, 2002.

145. Yagihashi N, Kasajima H, Sugai S, Matsumoto K, Ebina Y, Morita T, Murakami T and Yagihashi S: Increased in situ expression of nitric oxide synthase in human colorectal cancer. Virchows Arch 436: 109-114, 2000.

146. Rosbe KW, Prazma J, Petrusz P, Mims W, Ball SS and Weissler MC: Immunohistochemical characterization of nitric oxide synthase activity in squamous cell carcinoma of the head and neck. Otolaryngol Head Neck Surg 113: 541-549, 1995.

147. Brennan PA, Umar T, Smith GI, Lo CH and Tant S: Expression of nitric oxide synthase-2 in cutaneous squamous cell carcinoma of the head and neck. Br J Oral Maxillofac Surg 40: 191-194, 2002.

148. Brennan PA, Umar T, Bowden J, Hobkirk A, Spedding AV, Conroy B, Zaki G and Macpherson DW: Nitric oxide synthase expression is downregulated in basal cell carcinoma of the head and neck. Br J Oral Maxillofac Surg 38: 633-636, 2000.

149. Andrade SP, Hart IR and Piper PJ: Inhibitors of nitric oxide synthase selectively reduce flow in tumor-associated neovasculature. Br J Pharmacol 107: 1092-1095, 1992

150. Maeda H, Noguchi Y, Sato K and Akaike T: Enhanced vascular permeability in solid tumor is mediated by nitric oxide and inhibited by both new nitric oxide scavenger and nitric oxide synthase inhibitor. Jpn J Cancer Res 85: 331-334, 1994

151.Connelly ST, Macabeo-Ong M, Dekker N, Jordan RC and Schmidt BL: Increased nitric oxide levels and iNOS over-expression in oral squamous cell carcinoma. Oral Oncol 41: 261-267, 2005.

152. Vural P, Erzengin D, Canbaz M and Selçuki D: Nitric oxide and endothelin-1,2 in actinic keratosis and basal cell carcinoma: Changes in nitric oxide/endothelin ratio. Int J Dermatol 40: 704-708, 2001

153. Vidal MJ, Zocchi MR, Poggi A, Pellegatta F and Chierchia SL: Involvement of nitric oxide in tumor cell adhesion to cytokine-activated endothelial cells. J Cardiovasc Pharmacol 20 (Suppl 12): S155-S159, 1992.

154.Dong Z, Staroselsky AH, Qi X, Xie K and Fidler IJ: Inverse correlation between expression of inducible nitric oxide synthase activity and production of metastasis in K-1735 murine melanoma cells. Cancer Res 54: 789-793, 1994.

155. Brazeau P, Vale W, Burgus R, Ling N, Butcher M, Rivier J and Guillemin R: Hypothalamic polypeptide that inhibits the secretion of immunoreactive pituitary growth hormone. Science 179: 77-79, 1973.

156. Jin Z, Mori Y, Hamilton JP, Olaru A, Sato F, Yang J, Ito T, Kan T, Agarwal R and Meltzer SJ: Hypermethylation of the somatostatin promoter is a common, early event in human esophageal carcinogenesis. Cancer 112: 43-49, 2008.

157. Jackson K, Soutto M, Peng D, Hu T, Marshal D and El-Rifai W: Epigenetic silencing of somatostatin in gastric cancer. Dig Dis Sci 56: 125-130, 2011

158. Mori Y, Cai K, Cheng Y, Wang S, Paun B, Hamilton JP, Jin Z, Sato F, Berki AT, Kan T, et al: A genome-wide search identifies epigenetic silencing of somatostatin, tachykinin-1, and 5 other genes in colon cancer. Gastroenterology 131: 797-808, 2006.

159. Reubi JC and Laissue JA: Multiple actions of somatostatin in neoplastic disease. Trends Pharmacol Sci 16: 110-115, 1995.

160. Scambia G, Benedetti Panici P, Baiocchi G, Andreani C, Gaggini C, Giannelli S and Mancuso S: Growth inhibitory effect of somatostatin (SS) on human breast cancer cells in culture. J Steroid Biochem 28: 165, 1987.

161.Liebow C, Reilly C, Serrano M and Schally AV: Somatostatin analogues inhibit growth of pancreatic cancer by stimulating tyrosine phosphatase. Proc Natl Acad Sci USA 86: 2003-2007, 1989.

162. Taylor JE, Bogden AE, Moreau J-P and Coy DH: In vitro and in vivo inhibition of human small cell lung carcinoma (NCI-H69) growth by a somatostatin analogue. Biochem Biophys Res Commun 153: 81-86, 1988

163. Gill GN and Lazar CS: Increased phosphotyrosine content and inhibition of proliferation in EGF-treated A431 cells. Nature 293: 305-307, 1981. 
164. Mascardo RN and Sherline P: Somatostatin inhibits rapid centrosomal separation and cell proliferation induced by epidermal growth factor. Endocrinology 111: 1394-1396, 1982.

165. Kamiya Y, Ohmura E, Arai M, Fujii T, Hayakawa F, Ito J, Kawaguchi M, Tsushima T and Sakuma N: Effect of somatostatin and its analogue on proliferation of human epidermoid carcinoma cells in vitro. Biochem Biophys Res Commun 191: 302-307, 1993.

166. Burbach J and Wiegant V: Neuropeptides: basics and perspectives. de Wied D (ed). Elsevier, Amsterdam, pp45-103, 1990.

167. Thody AJ, Ridley K, Penny RJ, Chalmers R, Fisher C and Shuster S: MSH peptides are present in mammalian skin. Peptides 4: 813-816, 1983

168. SchauerE, TrautingerF,KöckA,Schwarz A,BhardwajR,Simon M, Ansel JC, Schwarz T and Luger TA: Proopiomelanocortin-derived peptides are synthesized and released by human keratinocytes. J Clin Invest 93: 2258-2262, 1994.

169. Slominski A and Mihm MC: Potential mechanism of skin response to stress. Int J Dermatol 35: 849-851, 1996.

170. Slominski A, Wortsman J, Luger T, Paus R and Solomon S: Corticotropin releasing hormone and proopiomelanocortin involvement in the cutaneous response to stress. Physiol Rev 80: 979-1020, 2000

171. Slominski AT, Botchkarev V, Choudhry M, Fazal N, Fechner K, Furkert J, Krause E, Roloff B, Sayeed M, Wei E, et al: Cutaneous expression of CRH and CRH-R. Is there a 'skin stress response system?'. Ann N Y Acad Sci 885: 287-311, 1999.

172. Slominski A, Zbytek B, Pisarchik A, Slominski RM, Zmijewski MA and Wortsman J: CRH functions as a growth factor/cytokine in the skin. J Cell Physiol 206: 780-791, 2006.

173. Slominski A, Wortsman J, Pisarchik A, Zbytek B, Linton EA, Mazurkiewicz JE and Wei ET: Cutaneous expression of corticotropin-releasing hormone (CRH), urocortin, and $\mathrm{CRH}$ receptors. FASEB J 15: 1678-1693, 2001

174. Slominski A, Pisarchik A, Tobin DJ, Mazurkiewicz JE and Wortsman J: Differential expression of a cutaneous corticotropin-releasing hormone system. Endocrinology 145: 941-950, 2004

175. Slominski A, Roloff B, Curry J, Dahiya M, Szczesniewski A and Wortsman J: The skin produces urocortin. J Clin Endocrinol Metab 85: 815-823, 2000.

176. Slominski A, Wortsman J, Mazurkiewicz JE, Matsuoka L, Dietrich J, Lawrence K, Gorbani A and Paus R: Detection of proopiomelanocortin-derived antigens in normal and pathologic human skin. J Lab Clin Med 122: 658-666, 1993.

177. Slominski A, Heasley D, Mazurkiewicz JE, Ermak G, Baker $\mathrm{J}$ and Carlson JA: Expression of proopiomelanocortin (POMC)-derived melanocyte-stimulating hormone (MSH) and adrenocorticotropic hormone (ACTH) peptides in skin of basal cell carcinoma patients. Hum Pathol 30: 208-215, 1999.

178. Slominski A: Identification of beta-endorphin, alpha-MSH and ACTH peptides in cultured human melanocytes, melanoma and squamous cell carcinoma cells by RP-HPLC. Exp Dermatol 7: 213-216, 1998.

179. Sato H, Nagashima Y, Chrousos GP, Ichihashi $M$ and Funasak Y: The expression of corticotropin-releasing hormone in melanoma. Pigment Cell Res 15: 98-103, 2002.

180. Slominski A and Pawelek J: Animals under the sun: Effects of ultraviolet radiation on mammalian skin. Clin Dermatol 16 503-515, 1998.

181. Scholzen TE, Brzoska T, Kalden D-H, O'Reilly F, Armstrong CA, Luger TA and Ansel JC: Effect of ultraviolet light on the release of neuropeptides and neuroendocrine hormones in the skin: Mediators of photodermatitis and cutaneous inflammation. J Investig Dermatol Symp Proc 4: 55-60, 1999.

182. Huang CM, Elmets CA, van Kampen KR, Desilva TS, Barnes S, Kim H and Tang DC: Prospective highlights of functional skin proteomics. Mass Spectrom Rev 24: 647-660, 2005.

183. Mitsuma T, Matsumoto Y and Tomita Y: Corticotropin releasing hormone stimulates proliferation of keratinocytes. Life Sci 69: 1991-1998, 2001.

184. Brown SL and Blalock JE: Neuroendocrine Immune Interactions. In: Immunophysiology: the Rrole of cells andcytokines in immunity and inflammation. Shevach JJOEM (ed). Oxford University Press, Oxford, pp306-319, 1990

185. Kim MH, Cho D, Kim HJ, Chong SJ, Lee KH, Yu DS, Park CJ, Lee JY, Cho BK and Park HJ: Investigation of the corticotropin-releasing hormone-proopiomelanocortin axis in various skin tumours. Br J Dermatol 155: 910-915, 2006.
186.Luger TA, Schauer E, Trautinger F, Krutmann J, Ansel J, Schwarz A and Schwarz T: Production of immunosuppressing melanotropins by human keratinocytes. Ann N Y Acad Sci 680 (1 The Melanotro): 567-570, 1993

187. Arbiser JL, Karalis K, Viswanathan A, Koike C, Anand-Apte B, Flynn E, Zetter B and Majzoub JA: Corticotropin-releasing hormone stimulates angiogenesis and epithelial tumor growth in the skin. J Invest Dermatol 113: 838-842, 1999.

188. Chakraborty AK, Funasaka Y, Slominski A, Ermak G, Hwang J, Pawelek JM and Ichihashi M: Production and release of proopiomelanocortin (POMC) derived peptides by human melanocytes and keratinocytes in culture: Regulation by ultraviolet B. Biochim Biophys Acta 1313: 130-138, 1996.

189.Ferjan I and Lipnik-Stangelj M: Chronic pain treatment: The influence of tricyclic antidepressants on serotonin release and uptake in mast cells. Mediators Inflamm 2013: 340473, 2013.

190.Ton BH, Chen Q, Gaina G, Tucureanu C, Georgescu A, Strungaru C, Flonta ML, Sah D and Ristoiu V: Activation profile of dorsal root ganglia Iba-1 (+) macrophages varies with the type of lesion in rats. Acta Histochem 115: 840-850, 2013.

191.Hart PH, Grimbaldeston MA, Swift GJ, Jaksic A, Noonan FP and Finlay-Jones JJ: Dermal mast cells determine susceptibility to ultraviolet B-induced systemic suppression of contact hypersensitivity responses in mice. J Exp Med 187: 2045-2053, 1998.

192. Kligman LH and Murphy GF: Ultraviolet B radiation increases hairless mouse mast cells in a dose-dependent manner and alters distribution of UV-induced mast cell growth factor. Photochem Photobiol 63: 123-127, 1996.

193. Byrne SN, Limón-Flores AY and Ullrich SE: Mast cell migration from the skin to the draining lymph nodes upon ultraviolet irradiation represents a key step in the induction of immune suppression. J Immunol 180: 4648-4655, 2008.

194. Maltby S, Khazaie K and McNagny KM: Mast cells in tumor growth: Angiogenesis, tissue remodelling and immune-modulation. Biochim Biophys Acta 1796: 19-26, 2009.

195. Ch'ng S, Wallis RA, Yuan L, Davis PF and Tan ST: Mast cells and cutaneous malignancies. Mod Pathol 19: 149-159, 2006.

196. Grimbaldeston MA, Skov L, Finlay-Jones JJ and Hart PH: Increased dermal mast cell prevalence and susceptibility to development of basal cell carcinoma in humans. Methods 28: 90-96, 2002

197.Humphreys TR, Monteiro MR and Murphy GF: Mast cells and dendritic cells in basal cell carcinoma stroma. Dermatol Surg 26: 200-203, discussion 203-204, 2000.

198. Hart PH, Grimbaldeston MA, Swift GJ, Hosszu EK and Finlay-Jones JJ: A critical role for dermal mast cells in cis-urocanic acid-induced systemic suppression of contact hypersensitivity responses in mice. Photochem Photobiol 70: 807-812, 1999

199. Garssen J, Buckley TL and Van Loveren H: A role for neuropeptides in UVB-induced systemic immunosuppression. Photochem Photobiol 68: 205-210, 1998

200. Wille JJ, Kydonieus AF and Murphy GF: cis-urocanic acid induces mast cell degranulation and release of preformed TNF-alpha: A possible mechanism linking UVB and cis-urocanic acid to immunosuppression of contact hypersensitivity. Skin Pharmacol Appl Skin Physiol 12: 18-27, 1999.

201. Khalil Z, Townley SL, Grimbaldeston MA, Finlay-Jones JJ and Hart PH: cis-Urocanic acid stimulates neuropeptide release from peripheral sensory nerves. J Invest Dermatol 117: 886-891, 2001.

202. Neagu M, Constantin C and Longo C: Chemokines in the melanoma metastasis biomarkers portrait. J Immunoassay Immunochem 36: 559-566, 2015.

203. Honeyman JF: Psychoneuroimmunology and the skin. Acta Derm Venereol 96: 38-46, 2016.

204. Ribatti D and Crivellato E: Mast cells, angiogenesis, and tumour growth. Biochim Biophys Acta 1822: 2-8, 2012.

205. Kanda N and Watanabe S: Histamine enhances the production of nerve growth factor in human keratinocytes. J Invest Dermatol 121: 570-577, 2003.

206. Hart PH, Grimbaldeston MA and Finlay-Jones JJ: Sunlight, immunosuppression and skin cancer: Role of histamine and mast cells. Clin Exp Pharmacol Physiol 28: 1-8, 2001.

207. Harizi H, Juzan M, Pitard V, Moreau JF and Gualde N: Cyclooxygenase-2-issued prostaglandin $\mathrm{e}(2)$ enhances the production of endogenous IL-10, which down-regulates dendritic cell functions. J Immunol 168: 2255-2263, 2002. 
208. Schwarz A, Ständer S, Berneburg M, Böhm M, Kulms D, van Steeg H, Grosse-Heitmeyer K, Krutmann J and Schwarz T: Interleukin-12 suppresses ultraviolet radiation-induced apoptosis by inducing DNA repair. Nat Cell Biol 4: 26-31, 2002.

209. Varricchi G, Galdiero MR, Marone G, Granata F, Borriello F and Marone G: Controversial role of mast cells in skin cancers. Exp Dermatol 26: 11-17, 2017

210.Sawatsubashi M, Yamada T, Fukushima N, Mizokami H, Tokunaga $\mathrm{O}$ and Shin T: Association of vascular endothelial growth factor and mast cells with angiogenesis in laryngeal squamous cell carcinoma. Virchows Arch 436: 243-248, 2000.

211. Diaconu NC, Kaminska R, Naukkarinen A, Harvima RJ and Harvima IT: The increase in tryptase- and chymase-positive mast cells is associated with partial inactivation of chymase and increase in protease inhibitors in basal cell carcinoma. J Eur Acad Dermatol Venereol 21: 908-915, 2007.
212.Hart PH, Townley SL, Grimbaldeston MA, Khalil Z and Finlay-Jones JJ: Mast cells, neuropeptides, histamine, and prostaglandins in UV-induced systemic immunosuppression. Methods 28: 79-89, 2002.

213. Townley SL, Grimbaldeston MA, Ferguson I, Rush RA, Zhang SH, Zhou XF, Conner JM, Finlay-Jones JJ and Hart PH: Nerve growth factor, neuropeptides, and mast cells in ultraviolet-B-induced systemic suppression of contact hypersensitivity responses in mice. J Invest Dermatol 118: 396-401, 2002.

214. Singh LK, Pang X, Alexacos N, Letourneau R and Theoharides TC: Acute immobilization stress triggers skin mast cell degranulation via corticotropin releasing hormone, neurotensin, and substance P: A link to neurogenic skin disorders. Brain Behav Immun 13: 225-239, 1999. 